\title{
PENGRAJIN TAHU DI DESA WALIAN KOTA TOMOHON
}

\author{
Zuldesmi \\ Jurusan Pendidikan Teknik Mesin, Fakultas Teknik, \\ Universitas Negeri Manado (UNIMA) \\ zuldesmi@unima.ac.id
}

\begin{abstract}
Abstrak
Tahu adalah salah satu jenis makan khas Indonesia yang banyak digemari oleh masyarakat Indonesia pada umumnya. Berdasarkan pengamatan dari tahapan-tahapan pekerjaan dalam proses pembuatan tahu, ditemukan satu tahapan pekerjaan yang memakan waktu cukup lama serta mengakibatkan tingkat kelelahan bagi para pekerjanya. Tahapan pekerjaan pada proses pembuatan tahu tersebut adalah pada tahapan proses pemotongan tahu. Hal ini terjadi karena pada tahapan pekerjaan tersebut masih dilakukan secara manual oleh para pengrajin tahu dengan menggunakan bantuan media penggaris dan pisau. Proses pengerjaannya juga masih dilakukan secara satu persatu sehingga banyak tersita waktu dan menyebabkan banyak pergerakan dari para pengrajin. Disamping itu karena cara mengerjakannya dilakukan dengan posisi badan membungkuk, sehingga mengakibatkan muncul rasa kelelahan yang tinggi bahkan juga menimbulkan rasa kesakitan yang berkepanjangan. Bertolak dari permasalahan di atas, pengusul dapat menemukan solusinya dengan cara mengganti metode dalam proses pekerjaan dari sistem manual ke sistem otomatisasi. Pada usulan kegiatan ini dilakukan melalui pengaplikasian alat bantu kerja dalam proses tahapan pemotongan tahu, sehingga produksi tahu yang dicetak dapat memiliki kualitas yang lebih baik dari sebelumnya, memiliki keseragaman ukuran, dan bentuk cetakan yang lebih halus dan rapi. Selain itu juga dapat mengefisiensikan waktu sehingga proses pekerjaan bisa lebih cepat dan jumlah kuantitas yang lebih banyak serta juga mendapatkan nilai ekonomis yang lebih tinggi. Tidak ketinggalan juga, selain dapat memaksimalkan produksi baik dari segi kuantitas maupun kualitas juga dapat mengurangi tingkat kelelahan dan kesakitan yang diderita oleh para pengrajin akibat dari penerapan metode pekerjaan yang masih bersifat manual.
\end{abstract}

Kata Kunci: Tahu, ergonomik, otomatisasi, efisien..

\section{PENDAHULUAN}

Tahu adalah salah satu jenis makan khas Indonesia yang banyak digemari oleh masyarakat Indonesia pada umumnya. Untuk memproduksi tahu yang bahan utamanya adalah kacang kedelai, harus melalui beberapa tahapan pekerjaan yang dimuali dari peredaman kacang kedelai, penggilingan kacang kedelai dengan penambahan air, lalu pemasakan dengan uap panas dan campuran air, lalu penyaringan ampas tahu, pencetakan dan pemotongan sesuai ukuran.
Berdasarkan pengamatan dari tahapantahapan pekerjaan dalam proses pembuatan tahu, ditemukan satu tahapan pekerjaan yang memakan waktu cukup lama serta mengakibatkan tingkat kelelahan bagi para pekerjanya. Tahapan pekerjaan pada proses pembuatan tahu tersebut adalah pada tahapan proses pemotongan tahu. Hal ini terjadi karena pada tahapan pekerjaan tersebut masih dilakukan secara manual oleh para pengrajin tahu dengan menggunakan bantuan media penggaris dan pisau. Proses pengerjaannya juga masih 
dilakukan secara satu persatu sehingga banyak tersita waktu dan menyebabkan banyak pergerakan dari para pengrajin. Disamping itu karena cara mengerjakannya dilakukan dengan posisi badan membungkuk, sehingga mengakibatkan muncul rasa kelelahan yang tinggi bahkan juga menimbulkan rasa kesakitan yang berkepanjangan.

Permasalahan yang timbul dari proses pengerjaan pembuatan tahu tersebut adalah merupakan permasalahan yang sering terdapat di semua tempat usaha pengrajin tahu yang masih menerapkan proses pekerjaan secara manual atau tradisional. Permasalahan ini juga berlaku atau dialami oleh usaha pengrajin tahu Maju Bersama yang dimiliki oleh bapak Wiyono dan berlokasi di kelurahan Walian Lingk. I Kecamatan Tomohon selatan, kota Tomohon. Usaha pengrajin tahu yang dimiliki oleh bapak Wiyono telah berproduksi sejak tahun 1999, untuk melayani permintaan tahu bagi masyarakat Tomohon, Minahasa Utara, Minahasa Selatan dan sekitarnya. Berdasarkan hasil wawancara, rata-rata produksi perhari yang dihasilkan oleh usaha tahu bapak Wiyono sekitar $400 \mathrm{~kg} /$ hari atau dalam bentuk produk tahu berkisar 19.000- 20.000 buah/hari. Jumlah tenaga kerja yang digunakan pada usaha tahu bapak Wiyono berjumlah 8 orang. Namun hingga saat ini usah tahu bapak Wiyono masih menerapkan metode pengerjaan yang bersifat manual atau tradisional. Pada proses pemotongan tahu yang dilakukan secara manual dengan menggunakan penggaris kayu dan pisau dapur, dibutuhkan waktu sekitar 60 menit setiap 1200 potong tahu (1200 buah/jam). Selain menyebabkan ketidaknyamanan dan rasa sakit pada bagian tubuh tertentu serta mudah lelah, rendahnya kualitas dalam tampilan menjadi masalah yang cukup signifikan karena banyak produksi tahu yang tidak seragam dalam ukuran dan bentuk. Disamping itu, masih belum tersedianya teknologi dan kemampuan dalam proses produksi dan pemasaran yang lebih praktis, efisien dan terorganisir.

Bertolak dari permasalahan di atas, pengusul dapat menemukan solusinya dengan cara mengganti metode dalam proses pekerjaan dari sistem manual ke sistem otomatisasi. Adapun metode otomatisasi adalah dengan menerapkan proses pengerjaan dengan bantuan alat atau mengaplikasikan alat bantu kerja dengan pendekatan ergonomik serta perancangan dan pengembangan produk. Penerapan dengan pendekatan ergonomik ini untuk menselerasikan pekerjaan dan lingkungan terhadap orang atau sebaliknya dengan tujuan tercapainya produktifitas dan efisiensi kerja yang setinggi-tingginya melalui pemanfaatan faktor manusia seoptimal-optimalnya.

Pada usulan kegiatan ini dilakukan melalui pengaplikasian alat bantu kerja dalam 
proses tahapan pemotongan tahu, sehingga produksi tahu yang dicetak dapat memiliki kualitas yang lebih baik dari sebelumnya, memiliki keseragaman ukuran, dan bentuk cetakan yang lebih halus dan rapi. Selain itu juga dapat mengefisiensikan waktu sehingga proses pekerjaan bisa lebih cepat dan jumlah kuantitas yang lebih banyak serta juga mendapatkan nilai ekonomis yang lebih tinggi. Tidak ketinggalan juga, selain dapat memaksimalkan produksi baik dari segi kuantitas maupun kualitas juga dapat mengurangi tingkat kelelahan dan kesakitan yang diderita oleh para pengrajin akibat dari penerapan metode pekerjaan yang masih bersifat manual.

\section{METODE PELAKSANAAN}

Meninjau permasalahan yang dihadapi oleh pengrajin tahu di atas, maka pengusul menggunakan metode penyelesaian melalui pembuatan alat pemotongan tahu dan beberapa pelatihan serta pendampingan dengan kegiatan yang terbagi menjadi dua bagian di bawah ini:

1. Selama Proses Produksi

Kegiatan yang dilakukan berupa pelatihan penggunaan alat bantu kerja dalam tahapan proses pekerjaan pemotongan tahu.

2. Pasca Produksi

Kegiatan yang dilakukan pada tahap ini berupa pendampingan manajemen keuangan dan strategi pemasaran melalui brosur dan iklan dengan tujuan untuk meningkatkan kemandirian masyarakat.

\section{HASIL DAN PEMBAHASAN}

Kegiatan yang sudah dilakukan sehubungan dengan hasil dan luaran yang dicapai pada kegiatan IbM kelompok usaha tahu di desa Walian Kota Tomohon adalah sebagai berikut:

1. Tersedianya alat potong tahu

Alat pemotong tahu berukuran $1.5 \mathrm{M} \mathrm{x}$ $1.0 \mathrm{M} \times \mathrm{H} 1.1 \mathrm{M}$ ini berfungsi sebagai pisau potong dengan spesifikasi ukuran tertentu, sesuai dengan ukuran yang dijual di pasaran. Alat ini dapat digunakan untuk memotong berbagai jenis tahu seperti : tahu biasa (regular tofu), tahu soft (soft tahu), dan juga tahu kering (dried tofu). Alat ini dibuat di bengkel PT. Bahagia Jaya Sejahtera. Alat ini sangat mudah digunakan dan cepat dalam proses penggantian pisau potongnya. Ukuran pemotongan tahu juga dapat diatur sesuai permintaan konsumen. Dengan memanfaatkan teknologi tersebut, waktu produksi dan jumlah produksi tahu akan meningkat signifikan.

2. Tahap pelatihan

Pelatihan dilaksanakan dua kali selama sebulan. Melalui pelatihan, para pekerja menjadi terampil dalam menggunakan alat potong tahu dan memahami perlunya peralatan penunjang yang digunakan untuk keselamatan kerja 
selama proses produksi tahu berlangsung. Kegiatan dilanjutkan pada tahap pelatihan manajemen keuangan dan strategi pemasaran melalui brosur dan iklan sehingga dapat meningkatkan kemandirian masyarakat. Melalui kegiatan pelatihan ini, terjadi peningkatan kemampuan mitra dalam manajemen keuangan sehingga menjadi lebih teratur, tertata dan mudah dipahami.

3. Tahap pelaksanaan

Setelah alat potong tahu tersedia dan melalui berbagai pelatihan, maka proses pemotong tahu dengan menggunakan alat potong tahu dipantau dan diamati oleh tim pelaksana. Semua pekerja dapat menggunakan alat dengan baik dan tahu yang dihasilkan lebih banyak dan memiliki bentuk yang seragam. Setelah dilakukan penghitungan, dapat disimpulkan bahwa dengan semakin singkatnya waktu pemotongan, maka jumlah produksi tahu yang dihasilkan semakin banyak yaitu dari yang semula 20.000 potong tahu/hari dengan metode manual meningkat menjadi sekitar 60.000-70.000 potong tahu/hari dengan menggunakan alat potong tahu. Sebelum digunakan alat bantu, jumlah tahu yang bisa dipotong sebanyak 1200 buah/jam. Waktu pemotongan semakin singkat ketika menggunakan alat potong tahu dan jumlah tahu yang dihasilkan meningkat menjadi 7000 buah/jam.
Yang lebih penting lagi adalah tahu dengan ukuran yang sama atau seragam dapat dihasilkan dengan menggunakan mesin pemotong tahu ini sehingga dapat memberikan tampilan yang bagus di pasaran. Selain itu, kelelahan dan keluhan rasa sakit di beberapa bagian tubuh pekerja dapat dihilangkan, sehingga pekerja dapat bekerja dengan nyaman.

4. Publikasi jurnal ilmiah

\section{KESIMPULAN DAN SARAN}

\section{Kesimpulan}

1. Kegiatan pengabdian mansyarakat yang dilakukan berjalan dengan baik berkat adanya kerjasama antara tim pelaksana dengan kelompok pengusaha tahu sebagai mitra kegiatan.

2. Kelelahan dan keluhan rasa sakit di beberapa bagian tubuh pekerja dapat dihilangkan, sehingga pekerja dapat bekerja dengan nyaman.

3. Dengan digunakannya alat potong tahu, ukuran tahu yang dihasilkan lebih seragam dan waktu proses pemotongan tahu dengan alat bantu menjadi lebih singkat dibandingkan tanpa alat bantu . Jumlah produksi tahun meningkat dari 20.000 buah/hari dengan manual menjadi 40.000 - 50.000 buah/hari dengan menggunakan alat bantu. 


\section{Saran}

Perlu adanya pendampingan dan komunikasi yang baik dengan kelompok usaha tahu agar usaha yang di jalani dapat berlangsung lama dan hasil yang diperoleh semakin meningkat.

\section{KEPUSTAKAAN}

Ahmad, Zaitu, 1999, Elemen Mesin I, refika Aditama, Bandung
McAtamney, L. and Corlett, E.N., 1993. Applied ergonomics, 24 (2), 91-9.

Nurminto Eko, 1996, Ergonomi Konsep Dasar dan Aplikasinya, Guna Widya, Semarang.

Amaha, K., Y. Sashi, and T. Segawa, 2007, Utilization of Tofu (Soybean Curd) ByProduct as Feed for Cattle. http/www.agnet.org. 
Jurnal ABDIMAS, Vol. 11, No. 2, Agustus 2018

ISSN: 1979-0953 | e-ISSN: 2598-6066 